\title{
Financial Deepening and Economic Growth in Nigeria: A Johannsen and Error Correction Model Techniques
}

\author{
Victoria Okafor ${ }^{1,2}$, Ebenezer Bowale ${ }^{1,2}$, Ademola Onabote ${ }^{2,3}$, Adedeji Afolabi ${ }^{2,4} \&$ Jeremiah Ejemeyovwi $^{1,2}$ \\ ${ }^{1}$ Department of Economics and Development Studies, Covenant University, Ota, Nigeria \\ ${ }^{2}$ Centre for Economic Policy and Development Research (CEPDeR), Covenant University, Ota, Nigeria \\ ${ }^{3}$ Department of Economics, Landmark University, Omu-Aran, Nigeria \\ ${ }^{4}$ Department of Building Technology, Covenant University, Ota, Nigeria \\ Correspondence: Victoria Okafor, Department of Economics and Development Studies, Covenant University, Ota, \\ Nigeria.
}

Received: June 23, 2020

Accepted: August 9, 2020

Online Published: January 14, 2021

doi:10.5430/ijfr.v12n2p263

URL: https://doi.org/10.5430/ijfr.v12n2p263

\begin{abstract}
The desire to ascertain the kind of relationship between finance and growth is not new among scholars. This study attempted to give a better understanding of the type of relationship by analysing post-SAP (Structural Adjustment Programme) time-series data since the notable financial reforms began with SAP in Nigeria. The study employed the Johannsen Cointegration, error correction and granger causality as estimation techniques to determine the nexus between financial deepening and economic growth. The variables contained in the model include the ratio of credit to the private sector to gross domestic product (CPS) which proxy bank-based financial deepening, the proportion of market capitalisation to gross domestic product (MCAP) which proxy for stock market development. The result of the analysis revealed that the Nigerian economic growth is influenced by financial deepening positively and significantly, especially the bank-based financial depth.
\end{abstract}

Keywords: economic growth, financial deeping, financial intermediaries, financial markets, market capitalisation

JEL code: G2, G21, E42

\section{Introduction}

Financial deepening is described as the growth and development of financial markets, financial intermediaries and financial institutions to make available financial resources in order to facilitate improved economic performance. A financial system that is properly developed would enable the correct mobilisation of resource to ensure its optimum use. An imperative role of financial deepening is the reduction in poverty according to Hassan, Sanchez, and Yu, (2011). Finance plays quite a central role as it ultimately determines the economic growth and development of countries. Over time, economic growth theory has claimed financial sector innovations enhance financial sector development and the economy as a whole.

According to Schumpeter (1911), financial intermediaries remain essential when it has to do with innovation and economic growth. That is advancement in technology influences economic growth and development of the financial structure. Review of literature showed that the mobilisation of capital, the distribution of resources, risk diversification, lead to economic growth which explains the financial intermediation theory (Jbili, Enders and Treichel, 1997) just as it is evident that the development of the financial market in emerging economies such as Nigeria, have a significant influence on the activities of banking institutions operations (Levine and Zervos, 1998; Khan and Senhadji, 2000).

Boyd and Prescott (1986) highlighted the role of financial institutions in promoting the distribution of capital resources for the development of companies brings about optimum resources allocation. In this case, banks become more productive than financial markets. As economies continue to develop, additional funds must be provided to address this rapid development, and the financial sector serves as an efficient means for mobilising and allocating capital between competitive needs, which are vital to the growth and productivity in the economy. Despite these observations, there exist conflicting views on how significant financial deepening is to an economy as Robinson (1952) 
put it that development of financial institutions such as the banks is a function of the growth of the economy. Similarly, Lucas (1988) noted that economists "seriously over-stressed" the role of financial growth. In other words, so much attention has been attached to the role of finance in determining economic development.

Nigeria has witnessed various formulation of policies targeted at reforming the financial sector with the aim of developing the country. The Banking sector is most notably recognised to have experienced series of reforms. Majorly, the financial sector reforms were designed purposely to maintain an effective and stable financial structure. The reforms sought to make it possible for the banking sector to build the stability required to support the economic growth of their country efficiently while performing its duties as a financial intermediary (Lemo, 2005). These reforms were either proposed in response to the on-going financial crisis in order to alleviate the impact of the crisis on the economy or to avert an impending crisis.

Literature is replete with the effect of financial deepening on economic growth still the extent of

financial deepening on economic growth has not been discussed exhaustively (Adeleye, Bowale, Matthew, Osabuohien and Oduntan 2017). Empirical literature, evidence showed contradictory findings on how economic growth is affected by financial deepening. Hasan et al., (2009) believe that economic growth and development requires a well-developed financial and economic institution. However, Choe and Moosa (1999), as well as Chang and Caudill (2005), argued that the leading driver of economic growth is finance, especially in developing countries. Therefore, there is a need for the role of financial deepening plays in economic growth to be examined due to the non-consensus of empirical findings. On that note, the precise objective is to carry out a re-examination of the nature of the relationship that exists between financial deepening and inclusive growth in the short and long run by employing variables to proxy the banking sector as well as stock market individually. The primary goals of the research are thus:

a. Assess if a long-run relationship exists between economic growth and financial deepening in Nigeria.

b. Ascertain the level of influence that financial deepening on the growth of the Nigerian economy.

c. Examine if financial reforms experienced in the financial sector have strengthened Nigerian economic development

d. Examine whether Nigeria has experienced growth in the economy due to financial sector reform.

\section{Review of Empirical Literature}

Using aggregate data of deposit money credit, the empirical connection between economic growth in Nigeria and financial deepening was studied by Azege (2004), and it was discovered that a positive relationship exists between economic growth and financial deepening in Nigeria. Nazmi (2005), carried out a similar study in five Latin American countries regarding financial deepening, deregulation and economic growth and its effect on capital accumulation using the general equilibrium model was developed for the analysis and a generalised method of moments (GMM) panel model estimation technique. The findings showed that capital accumulations and economic growth were positively influenced by financial deepening and deregulation. The study of Adams (1998) of the Nigeria economy found the mechanism of financial intermediation to be ineffective due to the low per capita income and rising inflation rates and insufficient banks. The method employed for the study is the two-stage least squares.

Agu and Chukwu (2009) results are somewhat divergent from most of the other Nigerian scholars as they employed the Johansen - Juselius and Toda - Yamamoto estimation technique in an attempt to study the economic growth in Nigeria for the period 1970-2015. The results of the Cointegration analysis indicated that only one cointegrating equation was present in the variables analysed, implying that a long-run relationship exists between economic growth and financial deepening. Their findings from the Toda-Yamamoto causality tests revealed evidence supporting both demand- and supply-led hypotheses. In 2013, Audu \& Okumoko, used data between the year 1970 to 2012 to examine how economic growth in Nigeria is affected by financial deepening. The study employed the ordinary least square estimation technique to analyse the existence of a long-run relationship among the six variables in the study, and it found that there was a long-run relationship between economic growth and financial development. However, whether the long-run relationship between economic growth and financial deepening was positive or not, the study failed to say.

An early study by (Nazmi, 2005) examined the role of the banking sector deregulation on capital accumulation leading to economic growth and development. The aim was to assess whether deregulation and financial deepening had a positive impact of on accumulation of capital. This led to the subjection of the financial sector to the general equilibrium model. A 35-year panel data were used from five Latin American countries and a dynamic generalised method of moment estimator was used to test the country-specific effects. From the findings, a positive and 
significant relationship is found which suggested that financial deepening play an essential role in securing investment for development. Adediran, Oduntan and Matthew (2017) using the ARDL technique, found a long-run relationship existed between financial development and inclusive growth after employing proportion of domestic credit to GDP as a proxy for financial development. This study did not pay attention to other variables that can proxy financial development like credit to the private sector.

However, some studies such as (Hasan et al., 2009 and Ho et al., 2018) emphasise the importance of a proper political institution in achieving economic development. Hasan et al., (2009) are of the opinion that that economic growth and development requires a well-developed financial and economic institution. They find that these institutions to be linked related positively to the growth. Similarly, the research by Ho et al. (2018) explores financial deepening, innovation and the role of political institution. The s study noted that financial development using innovation is possible with less interference from the government, but emphasised that a political democratisation condition does not necessary promotes innovation. A knowledge-based production model is employed, and estimation is conducted using the general method of moments. The study found a positive effect of a more democratic political regime on innovation. Besides, both the money and capital market are found to promote financial deepening when the states are more open.

Other study investigated for causality between financial deepening and economic growth. (See: Adeniyi et al., 2012; Gries et al., 2009; Karimo \& Ogbonna, 2017 ). While Adeniyi et al., (2012) and Gries et al. (2009) did not find any evidence of a causal relationship between financial deepening and economic growth, Karimo \& Ogbonna, (2017) findings are divergent. The role of a developed financial system is examined by Adeniyi et al. (2015). The study and concludes that a long-run cointegrating relationship exists between financial sector on economic growth, however, the extent to varies according to the lag period.

\section{Methods}

Several theories have been associated with the role of finance on the growth of an economy. These include; the Keynesian theory that favoured financial repression; the financial liberalisation hypothesis by Mckinnon and Shaw as well as the endogenous theory that supports the role of financial intermediation and markets to determine growth endogenously. The endogenous growth theory was, therefore employed for use in this study. Paul Romer and Robert Lucas's endogenous theory of growth emphasised the importance of human capital investments that promote economic growth by enhancing technological progress.

This study employed the use of time series data spanning 35 years from 1986 to 2016 . The choice of the period is to capture the Post SAP (Structural Adjustment Program) era when reforms in the financial sector started taking place. Consequently, the estimation technique in this study is the Cointegration technique which is best suited in capturing how financial deepening affects economic growth in the long run as well as the short-run dynamics. The E-views 9 application was used to analyse the secondary data to estimation the relationship between the variables. In the model specification, Real Gross Domestic Products (RGDP) at current prices is the explained variable, while the explanatory variables are capital, labour, credit to private sector, market capitalisation and lending interest rate.

Therefore,

$$
\operatorname{RGDP}_{\mathrm{t}}=\mathrm{f}\left(\mathrm{K}_{\mathrm{t}}, \mathrm{L}_{\mathrm{t}}, \mathrm{CPS}_{\mathrm{t}}, \mathrm{MCAP}_{\mathrm{t}}, \mathrm{LINR}_{\mathrm{t}}\right)
$$

The model expressed as an implicit function will be;

$$
\mathrm{Y}_{\mathrm{t}}=\mathrm{A} \mathrm{K}_{\mathrm{t}}^{\beta 1} \mathrm{~L}_{\mathrm{t}}^{\beta 2} \operatorname{CPS}_{\mathrm{t}}^{\beta 3} \operatorname{MCAP}_{\mathrm{t}}^{\beta 4} \operatorname{LINR}_{\mathrm{t}}^{\beta 5}
$$

However, equation (2) has to be linearised for it to be estimated, as shown in equation (3). Log-linearizing Equation 2 gives;

$$
\begin{gathered}
\operatorname{LogRGDP}_{\mathrm{t}}=\beta_{0}+\beta_{1} \log \mathrm{K}_{\mathrm{t}}+\beta_{2} \log \mathrm{L}_{\mathrm{t}}+\beta_{3} \log \mathrm{CPS}_{\mathrm{t}}+\beta_{4} \log \mathrm{MCAP}_{\mathrm{t}}+\beta_{5} \log \operatorname{LINR}_{\mathrm{t}}+\mu_{\mathrm{t}} \\
\operatorname{LogRGDP}_{\mathrm{t}}=\beta_{0}+\beta_{1} \log \mathrm{GFCF}_{\mathrm{t}}+\beta_{2} \log \mathrm{LABP}_{\mathrm{t}}+\beta_{4} \log \mathrm{CPS}_{\mathrm{t}}+\beta_{5} \log \mathrm{MCAP}_{\mathrm{t}}+\beta_{6} \log \log \mathrm{NR}+\mu_{\mathrm{t}}
\end{gathered}
$$

Where; RGDP: Real Gross Domestic Products; GFCF: Capital; LABP: Labour Participation; CPS: Credit to the private sector; MCAP: Market capitalisation; LINR: Lending interest rate; $t$ : period.

A priori expectations for the estimate parameters are $\beta_{0}>0, \beta_{1}>0, \beta_{2}>0, \beta_{3}>0 \beta_{4}>0$ while $\beta_{5}>0$ or $<0$. To verify the theoretical and statistical validity of the estimated coefficient, the unit root test was conducted using the Augmented Dickey-Fuller test. This was followed by the Johansen Cointegration test (Trace Statistics and Max Eigen statistics) to determine the long-run relationship, Error Correction Model (ECM) and the Granger Causality test. Data from 
secondary sources, such as the World Bank's World Development Indicators and Central Bank of Nigeria (CBN) Statistical Bulletin, were extracted for a 31 year period.

\section{Results}

The estimation as well as discussion of results is focused on in this section. The descriptive analysis showed the characteristics of each variable employed for the analysis while the econometric analysis quantitatively explained how economic growth in Nigeria is influenced by financial deepening. The results, the economic interpretation as well as implications of findings and recommendation, is included in this section.

\subsection{Descriptive Statistics}

This demonstrates the data characteristics used to carry out the research and its interpretation. In the study, a total of six data set were used in analysing the effect of financial deepening on economic growth. The data sets are real gross domestic product (RGDP), gross fixed capital formation (GFCF), Labour force participation (LAB), credit to private sector to GDP (CPS), ratio of market capitalisation to GDP (MCAP) and lending interest rate (LINR).

Table 1. Summary statistics of the variables

\begin{tabular}{|c|c|c|c|c|c|c|}
\hline Variables & $\begin{array}{c}\text { RGDP } \\
\text { (N' } \\
\text { Billion) }\end{array}$ & GFCF & LABP & CPS & MCAP & LINR \\
\hline Mean & 34530.04 & 11.07887 & 55.43005 & 4476.244 & 4801.194 & 18.82817 \\
\hline Median & 25267.54 & 11.74232 & 55.09933 & 764.9615 & 662.5000 & 17.98000 \\
\hline Maximum & 69023.93 & 16.55520 & 56.44551 & 21082.72 & 19077.42 & 29.80000 \\
\hline Minimum & 15237.99 & 5.458996 & 54.73632 & 15.24745 & 6.800000 & 10.50000 \\
\hline $\begin{array}{l}\text { Standard } \\
\text { Deviation }\end{array}$ & 18086.69 & 3.339221 & 0.605056 & 6594.423 & 6494.688 & 3.833205 \\
\hline Skewness & 0.708861 & -0.042447 & 0.661193 & 1.311135 & 1.018482 & 0.907319 \\
\hline Kurtosis & 2.026670 & 1.513162 & 1.835965 & 3.243366 & 2.453504 & 4.450245 \\
\hline Jarque-Bera & 3.819854 & 2.864779 & 4.008924 & 8.958393 & 5.745176 & 6.969986 \\
\hline Probability & 0.148091 & 0.238738 & 0.134733 & 0.011343 & 0.056552 & 0.030654 \\
\hline Sum & 1070431 & 343.4449 & 1718.331 & 138763.6 & 148837.0 & 583.6732 \\
\hline Sum Sq. Dev. & $9.81 \mathrm{E}+09$ & 334.5118 & 10.98280 & $1.30 \mathrm{E}+09$ & $1.27 \mathrm{E}+09$ & 440.8037 \\
\hline Observations & 31 & 31 & 31 & 31 & 31 & 31 \\
\hline
\end{tabular}

Source: Researcher's computation.

From Table 1, the result showed that real gross domestic product was highest in 2015 with 69,023 (N' Billion) and lowest RGDP in 1986 at 15,237 (N' Billion). The percentage of GFCF to GDP was highest in 2010 with a percentage of 16.55 percent and lowest value of 5.45 percent recorded in 2005. Labour force participation percentage of the total population was highest in 1990 with 56.45 percent and lowest at 54.73 percent in 2004. The ratio of credit to private sector to GDP, on the other hand, was highest in 2016 with a value of 21.08 (N' Billion) and lowest in 1986 with 15.25 (N' Billion) while the ratio of market capitalisation to GDP was highest in 2013 with a value of 19077.42 (N'Billion) and was as low as 6.8 (N' Billion) in 1986. Also, the lending interest rate was as high as 31.65 percent in 1993 and as low as 9.95 percent in 1986. All variables (RGDP, LABP CPS, MCAP and LINR) were positively skewed except GFCF. Examining the kurtosis, all variables (RGDP, GFCF, LAB, CPS, MCAP and LINR) had their kurtosis coefficient greater than zero which indicates that they are all leptokurtic. The Jarque-Bera statistics tested the null hypothesis that a series is normally distributed. The null hypothesis is rejected when the probability value is significant at 5 percent. Using the probability values as computed in Table 1, the variables, RGDP, GFCF, LAB, MCAP and CPS are not normally distributed except for LINR which is normally distributed as their respective probability values are not significant at 1 and 5 percent level of significance. 


\subsection{Unit Root Tests}

Stationarity test was performed on the time series data using Augmented Dickey Fuller (ADF) test. Times series data tend to have stationarity problem hence the need to carry out this test. For Cointegration test performed on a time series data, it is a prerequisite for the variables to be stationary and integrated of order one. If the critical value is less than the ADF statistics, the null hypothesis that states that the variable has no unit root will be rejected at the particular level of significance which is usually 5 percent level of significance.

Table 2. ADF unit root test

\begin{tabular}{lccccc}
\hline Variable & ADF Statistic & \multicolumn{3}{c}{ Critical value } & $\begin{array}{c}\text { Order of } \\
\text { integration }\end{array}$ \\
\cline { 3 - 6 } & & $\mathbf{1 \%}$ & $\mathbf{5 \%}$ & $\mathbf{1 0 \%}$ & \\
\hline Real GDP & -2.929176 & -3.679322 & -2.967767 & -2.622989 & I (1) \\
GFCF & -5.682771 & -4.323979 & -3.580623 & -3.225334 & I (1) \\
LABP & -2.414484 & -2.647120 & -1.952910 & -1.610011 & I (1) \\
CPS & -5.971963 & -3.769597 & -3.004861 & -2.642242 & I (1) \\
MCAP & -3.804020 & -3.711457 & -2.981038 & -2.629906 & I (1) \\
LINR & -4.860502 & -3.737853 & -2.991878 & -2.635542 & I (1) \\
\hline
\end{tabular}

Source: Researcher's computation.

Table 2 shows the findings of the unit root test where all the variables were integrated of order one. The variables tested as seen in table 2, had ADF statistics that was higher than the critical level at 5 percent level of significance.

\subsection{Johansen Cointegration Test}

According to economic theory, it is expected that certain subset variables, for instance, finance and growth to be jointly influenced in the long run. However, circumstances in the economy whether foreseen or unforeseen can cause these variables to move away from equilibrium; hence it is expected that economic forces or intervention by the government will restore equilibrium. Johansen Cointegration test is used to analyse variables for the existence of long-run relationship between them. When a long-run equilibrium relationship is present between two or more variables, cointegration is said to have taken place (Binh, 2013).

Table 3. Johansen cointegration test (trace statistic)

\begin{tabular}{lcccc}
\hline $\begin{array}{l}\text { Hypothesized } \\
\text { No. of CE(s) }\end{array}$ & Eigenvalue & $\begin{array}{c}\text { Trace } \\
\text { Statistic }\end{array}$ & $\begin{array}{c}\mathbf{0 . 0 5} \\
\text { Critical Value }\end{array}$ & Prob.** \\
\hline None * & 0.760704 & 122.8118 & 95.75366 & 0.0002 \\
At most 1 * & 0.683590 & 81.34027 & 69.81889 & 0.0046 \\
At most 2* & 0.542251 & 47.96945 & 47.85613 & 0.0488 \\
At most 3 & 0.380283 & 25.30785 & 29.79707 & 0.1507 \\
At most 4 & 0.325317 & 11.43158 & 15.49471 & 0.1863 \\
At most 5 & 0.000679 & 0.019711 & 3.841466 & 0.8882 \\
\hline
\end{tabular}

* denotes rejection of the null hypothesis at the 0.05 level

**MacKinnon-Haug-Michelis (1999) p-values

Source: Researcher's Computation. 
Table 3 showed the breakdown of the test result of the cointegration test using Trace Statistics. The findings indicated the presence of long-run relationship equilibrium among the variables. It implies that at a 5 percent level of significance, three cointegrating equations exist among the variables tested. Therefore, the alternative hypothesis stating the existence of a cointegrating relationship among the variables is as a result of this accepted. In contrast, the null hypothesis is rejected at a 5 percent level of significance. Hence, there exist long-run equilibrium relationships between RGDP, GFCF, LAB, CPS, MCAP and LINR.

Table 4. Johansen cointegration test (Max-Eigen statistic)

\begin{tabular}{lcccc}
\hline $\begin{array}{l}\text { Hypothesized } \\
\text { No. of CE(s) }\end{array}$ & Eigenvalue & $\begin{array}{c}\text { Max-Eigen } \\
\text { Statistic }\end{array}$ & $\begin{array}{c}\mathbf{0 . 0 5} \\
\text { Critical Value }\end{array}$ & Prob.** \\
\hline None ${ }^{*}$ & & 41.47157 & 40.07757 & 0.0346 \\
At most 1 & 0.760704 & 33.37082 & 33.87687 & 0.0573 \\
At most 2 & 0.683590 & 22.66160 & 27.58434 & 0.1884 \\
At most 3 & 0.380283 & 13.87627 & 21.13162 & 0.3753 \\
At most 4 & 0.325317 & 11.41186 & 14.26460 & 0.1347 \\
At most 5 & 0.000679 & 4.796705 & 3.841466 & 0.8882 \\
\hline
\end{tabular}

* denotes rejection of the null hypothesis at the 0.05 level

***MacKinnon-Haug-Michelis (1999) p-values

Source: Researcher's computation, 2018.

Additionally, Table 4 describes the cointegration test among the variable using Max-Eigen Statistics. It indicated the existence of only one cointegrating equation signifying the presence of a long-run relationship between variables.

Table 5. Normalised cointegration coefficients (standard error in parentheses)

\begin{tabular}{lllllll}
\hline & Real GDP & GFCF & LABP & CPS & MCAP & LINR \\
\hline & 1.000000 & -4752.133 & 30166.78 & 3.115429 & -4.355104 & -60.0565 \\
S. Error & & $(676.693)$ & $(4169.17)$ & $(0.70959)$ & $(0.63998)$ & $(372.915$ \\
T-Statistic & -7.0226 & 7.23568 & 4.390464 & -6.80506 & -0.16105 \\
\hline
\end{tabular}

Source: Researcher's Computation, 2018.

From Table 5, the coefficients and statistical significance of the explanatory variables as well as how the variables affect economic growth can be deduced. The result explains that an increase in GFCF by a unit will cause economic growth to increase significantly by 4752.133 units since the T-statistics is greater than 2. A unit change in Labour force participation will lead to about 30166.78 unit decrease in economic growth which is also statistically significant at 5 percent level of significance. Furthermore, when CPS is increased by a unit, there will be a significant decrease in economic growth by 3.1154. However, an increase in Marketcapitalisation by a unit will bring about a positive increase in economic growth by 4.3551 . This increase is significant at the 5 percent. The result of the lending rate is not significant because the T-statistics happen to be less than two, as shown in the table. 


\subsection{Error Correction Model (ECM)}

Granger (1981) first made known the relationship between cointegration and error correction model. According to Kanioura and Turner (2003), the use of error correction model in applied econometrics goes back to the study by Sargan (1964). Error correction model explains the behaviour of variables in the short run following the presence of a long-run relationship. It is long-run properties that are considered by the cointegrating regression without regard for the short-run dynamics (Kanioura and Turner, 2003). Hence, the error correction model is used to analyse the short-run equilibrium behaviour of the variables. Over the cause of long-run equilibrium, it is expected that a disturbance will occur to shift the variables from equilibrium; hence, the variables have to react in the short run interim. How the variables interact in this interim is what the error correction model seeks to analyse. It is assumed that a disequilibrium proportion for the period is corrected in the next period, which is the basis for the error correction mechanism. The existence of a cointegrating relationship is the basis for carrying out an error correction analysis. Since the result of the Cointegration test above confirms that a long-run relationship exists between the variables, it is essential that the error correction analysis is performed to explain the short-run equilibrium dynamics.

Table 6. Summary of Error Correction Model (ECM) result

\begin{tabular}{lccc}
\hline Variables & Coefficient & Std. Error & T-statistic \\
\hline ECM (-1) & -0.3945 & 0.1282 & -3.0772 \\
D(Real GDP (-1)) & 0.1435 & 0.2145 & 2.8754 \\
D(Real GDP (-2)) & 0.6347 & 0.2839 & 2.2357 \\
D(GFCF (-1)) & -458.3923 & 127.79 & -3.5870 \\
D(GFCF (-2)) & -533.5902 & 111.991 & -4.7646 \\
D(LABP (-1)) & 4851.057 & 2204.14 & 2.2009 \\
D(LABP (-2)) & 5312.307 & 2066.06 & 2.5712 \\
D(CPS (-1)) & 0.1825 & 0.1875 & 0.9733 \\
D(CPS (-2)) & 0.5211 & 0.1915 & 2.7215 \\
D(MCAP (-1)) & -0.1226 & 0.1175 & -1.0432 \\
D(MCAP (-2)) & -0.0107 & 0.1020 & -0.1049 \\
D(LINR (-1)) & -15.4785 & 59.5719 & -0.2598 \\
D(LINR (-2)) & -77.5525 & 44.9090 & -1.7269 \\
C & -367.0262 & 595.536 & -0.6163 \\
\hline
\end{tabular}

Source: Researcher's Computation, 2018.

The rule of thumb in the error correction model states that the error term must be negative and lay between zero and one. Table 6 indicates that the error term, ECM (-1) is (-0.3945), and this agrees with the rule of thumb the condition of being negative and lying between 0 and 1 . The implication is that if disequilibrium should occur in the economy, the variables will return to equilibrium with a speed of 39 percent. There will be a 39 percent adjustment speed in the case of disequilibrium in the economy. Also, since the T statistics is 3.0772, the error term is statistically significant at 5 percent level of significance. The one lag period coefficient of the variables Real GDP, GCFC, LABP, CPS, MCAP, LINR are (0.1435), (-458.3923), (4851.057), (0.1825), (-0.1226) and (-15.4785) respectively as shown in Table 4 . These coefficients showed the short-run dynamics of the variables.

\subsection{Granger Causality Test}

This test is very helpful in forecasting the behaviour of the variables in the long run. It explains linear predictions and suggests that one thing happens before another, not actually meaning one thing causes the other to happen. The test helps to determine in this case whether financial deepening need to take place before economic growth can happen or the economy need to grow before financial deepening can be achieved. The null hypothesis is rejected if the probability value is less than 0.05 according to the statistical significance at 5 percent. 
Table 7. Pairwise granger causality test

\begin{tabular}{|c|c|c|c|}
\hline Null Hypothesis: & Obs. & F-Statistic & Prob. \\
\hline GFCF does not Granger Cause REALGDP & 29 & 1.34722 & 0.2789 \\
\hline REALGDP does not Granger Cause GFCF & & 1.74976 & 0.1953 \\
\hline LABP does not Granger Cause REALGDP & 29 & 4.01738 & 0.0313 \\
\hline REALGDP does not Granger Cause LABP & & 0.57705 & 0.5692 \\
\hline CPS does not Granger Cause REALGDP & 29 & 4.10768 & 0.0292 \\
\hline REALGDP does not Granger Cause CPS & & 8.16389 & 0.0020 \\
\hline MCAP does not Granger Cause REALGDP & 29 & 0.26788 & 0.7673 \\
\hline REALGDP does not Granger Cause MCAP & & 11.0951 & 0.0004 \\
\hline LINR does not Granger Cause REALGDP & 29 & 1.75591 & 0.1942 \\
\hline REALGDP does not Granger Cause LINR & & 2.64419 & 0.0917 \\
\hline LABP does not Granger Cause GFCF & 29 & 5.35412 & 0.0119 \\
\hline GFCF does not Granger Cause LABP & & 1.30404 & 0.2900 \\
\hline CPS does not Granger Cause GFCF & 29 & 3.27916 & 0.0551 \\
\hline GFCF does not Granger Cause CPS & & 0.16319 & 0.8504 \\
\hline MCAP does not Granger Cause GFCF & 29 & 4.02533 & 0.0311 \\
\hline GFCF does not Granger Cause MCAP & & 0.33546 & 0.7183 \\
\hline LINR does not Granger Cause GFCF & 29 & 1.91373 & 0.1694 \\
\hline GFCF does not Granger Cause LINR & & 0.56254 & 0.5771 \\
\hline CPS does not Granger Cause LABP & 29 & 0.60992 & 0.5516 \\
\hline LABP does not Granger Cause CPS & & 2.35793 & 0.1162 \\
\hline MCAP does not Granger Cause LABP & 29 & 0.55079 & 0.5836 \\
\hline LABP does not Granger Cause MCAP & & 1.82401 & 0.1830 \\
\hline LINR does not Granger Cause LABP & 29 & 2.58904 & 0.0959 \\
\hline LABP does not Granger Cause LINR & & 3.47825 & 0.0472 \\
\hline MCAP does not Granger Cause CPS & 29 & 7.95792 & 0.0022 \\
\hline CPS does not Granger Cause MCAP & & 2.41325 & 0.1109 \\
\hline LINR does not Granger Cause CPS & 29 & 0.71114 & 0.5011 \\
\hline CPS does not Granger Cause LINR & & 1.32894 & 0.2835 \\
\hline LINR does not Granger Cause MCAP & 29 & 0.14415 & 0.8665 \\
\hline MCAP does not Granger Cause LINR & & 2.32270 & 0.1196 \\
\hline
\end{tabular}

Source: Researcher's Computation, 2018.

Table 7 shows the result of the Pairwise Granger causality test. Based on the decision rule, the alternative hypothesis that Real GDP granger causes CPS is accepted since the null hypothesis is rejected. Similarly, the null hypothesis that CPS does not granger causes Real GDP is rejected, thus implying the presence of a bi-directional relationship between Real GDP and CPS. Additionally, the null hypothesis that Real GDP does not granger causes MCAP is rejected, but the null hypothesis that MCAP does not granger causes Real GDP is accepted. This signifies the existence of a uni-directional relationship between MCAP and Real GDP with the relationship running from Real GDP to MCAP. In the directional relationship between MCAP and CPS, the null hypothesis that MCAP does not granger causes CPS is rejected while the Null hypothesis that CPS does not granger causes MCAP is accepted. Thus, evidently showing that a uni-directional relationship exists between MCAP and CPS with the direction running from MCAP to CPS.

The causality result explains that a feedback relationship exists between banking based financial deepening and economic growth since CPS proxies the bank-based financial deepening. That is, while economic growth will lead to bank-based financial depth, bank-based financial depth equally enhances economic growth. Whereas, economic 
growth only promotes stock market based financial deepening since a uni-directional relationship exists between Real GDP and MCAP with the direction running from Real GDP to MCAP. And MCAP proxied market capitalisation which is the market based financial deepening. Furthermore, market capitalisation enhances bank-based financial deepening as a uni-directional relationship running from MCAP to CPS exists between MCAP and CPS

\section{Implication of Findings}

This study employed a Cointegration estimation technique to determine the nature of the relationship that existed between financial deepening and economic growth in Nigeria and discovered the existence of a long-run relationship between the variables. The variables employed in the study all conformed to apriori expectation except for Credit to Private Sector (CPS). The result showed that CPS is more than likely to affect economic growth negatively in the long run. In practical terms, financial institutions in Nigeria have not fully developed or are not maximising their full potentials, thereby limiting its productive functions to the economy. Also, evidence from developing countries similar to Nigeria as observed by Sahay et al. (2015) indicated that as the economy evolves, the relative benefit of financial institutions decreases while those from financial markets increases.

Therefore, the financial institutions, in the long run, are expected to evolve with the economy, which explains the decline in their relative benefit to the society and positive contribution of the financial sector. This could be further emphasised by the result from the pairwise Granger, which indicated a feedback relationship between economic growth and credit to the private sector; hence, economic growth and banking institutions develop simultaneously. Consequently, as the banking sector grows, it enhances economic growth and economic growth increases the demand for finance in the economy thereby instigating the banking institutions to be more efficient in meeting the demand for financial goods and services. This means that if economic growth must happen, financial deepening must be triggered and vice versa.

Additionally, credit to the private sector and market capitalisation exhibited the presence of un-directional relationship from market capitalisation to credit to the private sector. According to literature, the development of the financial markets leads to an increase in bank deposits, thereby promoting efficiency in the banking system. Therefore, policies that encourage both aspects of finance without one being at the detriment of the other should be recommended. However, the relationship between the lending interest rate and economic growth indicated a positive. It was an expected outcome since the lending interest rate reported financial reforms that occurred in the financial sector for the period observed.

\section{Summary, Conclusion and Recommendations}

The objective of this paper was to examine how economic growth in Nigeria was affected by financial deepening from 1986 to 2016 while paying attention to the financial reforms that took place during the period. The study employed the use of variables relevant to the research such as Real Gross Domestic Product, Market capitalisation, Credit to private Sector, Lending Interest rates, labour participation and Gross Fixed Capital Formation. The Cointegration estimation technique was used to analyse the variables and test for the presence of a long-run relationship between them. To test for the causality among the variables, the Pairwise Granger causality test was performed as well as other tests like unit root test to test for stationarity and error correction model for short-run dynamics test.

The study actualised its objectives the Cointegration approach, descriptive analysis and the Granger causality test. With the cointegration estimation technique, it was discovered that a long-run relationship existed between economic growth and financial deepening. Also, evidence from the granger causality test indicated the presence of a bi-directional causality relationship economic growth and financial deepening. This signified that the economy has to grow for financial deepening to take place and financial deepening has to take place to promote economic growth. Also, the financial sector reforms indicator, which is the lending interest rate indicated that a positive long-run relationship existed between the reforms and economic growth, although it was statistically insignificant.

The financial market proxy, market capitalisation exhibited a positive relationship with economic growth in the long run. However, CPS and Labour force participation showed a negative relationship with economic growth in the long run. Another significant finding by the study was the existence of a feedback causality relationship from economic growth to financial deepening and from financial deepening to economic growth. The error correction also indicated that the economy would adjust with a speed of 39 percent back to equilibrium when disequilibrium occurs in the economy. Following the findings, the study makes the following recommendations; 
- It is important that emphasis should be placed on implementing reforms in the financial sector that capture long term as well as short term implications on all sectors. That is, since the control variable, lending interest rate, positively affected economic growth in the long run, it is profitable to promote reforms will have positive effect on the market based financial system as well as banked based.

- $\quad$ Furthermore, there should be a promotion of policies that enhance the development of both the bank sector and financial markets so that the banks and stock market could rise simultaneously to enable the provision of various financial bundles without one suffering at the expense of the other.

- Policies encouraging a healthy macro-economic environment should be implemented to trigger financial sector development and reduce the incidence of non-performing credit, thereby enabling credit to be channelled from the domestic sector to the real economy.

This study recommends that further study areas should be done on financial deepening and economic growth on a regional level since the author has been able to establish that financial deepening varies from financial development in an economy. While numerous literatures tend to focus more on the latter, the former also plays an essential role in the economy. This will contribute to the body of literature as there are few studies on financial deepening which constituted a limitation in the study.

\section{Acknowledgement}

This paper was extracted from the Masters research of the lead author conducted as a postgraduate student at Covenant University; therefore, the authors appreciate the comments and suggestions from the faculty of the department that helped make the research better. Also, the authors of this article give many thanks to the Covenant University Centre for Research, Innovation and Discovery (CUCRID) for their financial support in publishing this paper.

\section{References}

Adams, J. (1998). Financial intermediation on economic growth: evidence from Nigeria. Journal of Economic Management, 27-40.

Adediran, O. S., Oduntan, E., \& Matthew, O. (2017). Financial development and inclusive growth in Nigeria: A multivariate approach. Journal of Internet Banking and Commerce, 22(8), 14.

Adeleye, N., Osabuohien, E., Bowale, E., Matthew, O., \& Oduntan, E. (2017, October)). Financial reforms and credit growth in Nigeria: empirical insights from ARDL and ECM techniques. International Review of Applied Economics, 2171, 1-14. https://doi.org/10.1080/02692171.2017.1375466

Adeniyi, O., Oyinlola, A., Omisakin, O., \& Egwaikhide, F. O. (2015). Financial development and economic growth in Nigeria: Evidence from threshold modelling. Economic Analysis and Policy, 47, 11-21. https://doi.org/10.1016/j.eap.2015.06.003.

Agu, C., \& Chukwu, J. (2009). Multivariate causality between financial depth and economic growth in Nigeria. African Review of Money, Finance and Banking, 7-21.

Azege, M. (2004). The impact of financial intermediation on economic growth: The Nigerian perspective. Research Conference Paper for Lagos State University. Lagos: Lagos State University.

Binh, P. T. (2013). Unit root tests, Cointegration, ECM, VECM and Causality model. Topics in Time Series Econometrics.

Boyd, J. H., \& Prescott, E. C. (1986). Financial intermediary-coalitions. Journal of Economic Theory, 38(2), 211-232.

Chang, T., \& Caudill, S. B. (2005). Financial development and economic growth: a case of Taiwan. Applied Economics, 37(12), 1329-1335.

Choe, C., \& Moosa, I. A. (1999). Financial system and Economic Growth: the Korean experience. World Development, 27(6), 1069-1082.

Granger, C. W. J. (1981). Some properties of time series and their use in econometric model specification. Journal of Econometrics, 16, 121-130.

Granger, C. W. J. (1983). Cointegrated variables and error correction models. UCSD Discussion Paper 83-13a.

Greene, W. H. (2003). Econometric Analysis (5th ed., p. 382). Pearson Education.

Greenwood, J., \& Jovanovic, B. (1990). Financial development, growth and the distribution of income. Journal of Political Economy, 98(5), 1076-1107. 
Gries, T., Kraft, M., \& Meierrieks, D. (2009). Linkages between financial deepening, trade openness, and economic development: causality evidence from Sub-Saharan Africa. World Development, 37(12), 1849-1860. https://doi.org/10.1016/j.worlddev.2009.05.008

Hasan, I., Wachtel, P., \& Zhou, M. (2009). Institutional development, financial deepening and economic growth: Evidence from China. Journal of Banking \& Finance, 33(1), 157-170. https://doi.org/10.1016/j.jbankfin.2007.11.016

Hassan, M. K., Sanchez, B., \& Yu, J. (2011). Financial development and economic growth: New evidence from panel data. Quarterly Review of Economics and Finance, 51(1), 88-104. https://doi.org/10.1016/j.qref.2010.09.001

Ho, C.-Y., Huang, S., Shi, H., \& Wu, J. (2018). Financial deepening and innovation: The role of political institutions. World Development, 109, 1-13. https://doi.org/10.1016/j.worlddev.2018.02.022

Hye, Q., \& Islam, F. (2012). Does Financial development hampers economic growth: empirical evidence from Bangladesh. Journal of Risk Financing, 558-582.

Jbili, A., Enders, K., \& Treichel, V. (1997, September). Financial sector reforms in Morocco and Tunisia. Finance and Development, 29-31.

Kanioura, A., \& Turner, P. (2003). The error correction model as a test for cointegration. Sheffield Economic Research Paper Series.

Karimo, T., \& Ogbonna, O. (2017). Financial deepening and economic growth nexus in Nigeria: Supply-leading or demand-following?. Economies, 5(1), 4. https://doi.org/10.3390/economies5010004

Khan, S. M., \& Senhadji, S. A. (2000). Financial development and economic growth: An overview. World Development, 3. https://doi.org/10.1016/j.jdeveco.2010.10.005

Lemo, T. (2005). Regulatory Oversight and Stakeholder Protection. A Paper Presented at the BGL Mergers and and acquisition interaction seminar, held at Eko Hotel and Suit, V.I, Lagos, Nigeria, June 24. Lagos.

Levine, R., \& Zervos, S. (1998). Stock markets, banks, and economic growth. American Economic Review, 88(3), 537-558.

Lucas, R. E. (1988). On the mechanics of economic development. Journal of Monetary Economics, 22(1), 3-42.

Nazmi, N. (2005). Deregulation, financial deepening and economic growth: The case of Latin America. The Quarterly Review of Economics and Finance, 45(2), 447-459. https://doi.org/10.1016/j.qref.2004.12.014

Nkoro, E., \& Uko, A. (2013). Financial sector development-economic growth Nexus: Empirical evidence from Nigeria. American International Journal of Contemporary Research, 87-94.

Odeniran, S., \& Udeaja, E. (2010). Financial Sector development and economic growth: Empirical evidence from Nigeria. Central Bank Nigeria Economic and Finance Review, 92-124.

Omotor, D. (2007). Financial development and Economic growth: Evidence from Nigeria. Nigerian Journal of Economics and Social Studies, 209-234.

Osuji, C., \& Chigbu, E. (2012). An evaluation of Financial and economic growth of Nigeria: A causality test. Kuwait Chapter of Arabian Journal of Business and Management Review, 27-44.

Robinson, J. (1952). The Generalisation of the General Theory: the interest rate and other essays. London: Macmillan.

Sahay, R., Čihák, M., Diaye, P. N., Bi, R., Ayala, D., Gao, Y., \& Yousefi, S. R. (2015). Rethinking financial deepening: Stability and growth in emerging markets. International Monetary Fund (IMF): IMF staff discussion note.

Sargan, J. (1964). Wages and prices in the United Kingdom: A study in econometric methodology. Econometric Analysis for National Economic Planning, 16, 25-63.

Schumpeter, J. A. (1911). The theory of economic development. Cambridge: Harvard University Press.

\section{Copyrights}

Copyright for this article is retained by the author(s), with first publication rights granted to the journal.

This is an open-access article distributed under the terms and conditions of the Creative Commons Attribution license (http://creativecommons.org/licenses/by/4.0/). 